\title{
Thrombotest dilution curve
}

Citation for published version (APA):

Hemker, H. C. (1978). Thrombotest dilution curve. Thrombosis and Haemostasis, 39(1), 240. https://doi.org/10.1055/s-0038-1646678

Document status and date:

Published: 01/01/1978

DOI:

10.1055/s-0038-1646678

Document Version:

Other version

\section{Please check the document version of this publication:}

- A submitted manuscript is the version of the article upon submission and before peer-review. There can be important differences between the submitted version and the official published version of record.

People interested in the research are advised to contact the author for the final version of the publication, or visit the DOI to the publisher's website.

- The final author version and the galley proof are versions of the publication after peer review.

- The final published version features the final layout of the paper including the volume, issue and page numbers.

Link to publication

\footnotetext{
General rights rights.

- You may freely distribute the URL identifying the publication in the public portal. please follow below link for the End User Agreement:

www.umlib.nl/taverne-license

Take down policy

If you believe that this document breaches copyright please contact us at:

repository@maastrichtuniversity.nl

providing details and we will investigate your claim.
}

Copyright and moral rights for the publications made accessible in the public portal are retained by the authors and/or other copyright owners and it is a condition of accessing publications that users recognise and abide by the legal requirements associated with these

- Users may download and print one copy of any publication from the public portal for the purpose of private study or research.

- You may not further distribute the material or use it for any profit-making activity or commercial gain

If the publication is distributed under the terms of Article $25 \mathrm{fa}$ of the Dutch Copyright Act, indicated by the "Taverne" license above, 


\section{THROMBOSIS \\ AND HAEMOSTASIS}

\section{(formerly Thrombosis et Diathesis Haemorrhagica)}

Journal of the International Society on Thrombosis and Haemostasis
No. $1 \cdot$ Vol. 39

February 28, 1978

Editor:

Dr. Rosemary Biggs, Oxford

Associate Editors: C. R. Rizza, Oxford · F. Duckert, Basel · H. R. Roberts, Chapel Hill · P. N. Walsh, Philadelphia J. P. Caen, Paris · V. J. Marder, Philadelphia - E. A. Beck, Bern

\section{Letter to the Editor}

\section{Thrombotest Dilution Curve}




\title{
Thrombotest Dilution Curve
}

October 27, 1977

Dear Madam,

With much interest I read the remarks of Dr. A. Girolami on the paper of Briet et al. He is essentially right in stating that a plasma deficient in one coagulation factor will show in the thrombotest dilution curve a line intercepting the ordinate at a point higher than that for normal plasma. The reason for this phenomenon is simple. With normal plasmas or plasmas in which the rate limiting clotting factors (II, VII, X) are deficient to about the same extent extrapolation to the ordinate is extrapolation to a situation in which all three clotting factors are present in infinite amounts.

When one of the factors is lacking - in the most extreme case absent - extrapolation to infinite concentrations will still represent a situation in which the lacking factor is rate limiting, i.e. a high clotting time.

Careful reading of our articles "Kinetic aspects of the interaction of coagulation factors" I-VII (Thrombosis and Haemostasis 1965-1977) and of the literature cited therein will show that from the beginning we have been aware of this fact. The detection of inhibitors by the thrombotest dilution curve is only possible when no specific deficiencies exist. The remarks of Dr. Girolami are not superfluous though, as I have observed that time and again aberrant dilution curves are too easily interpreted in terms of inhibitory substance present. It is absolutely not true that Lineweaver-Burk plots are found only in single enzyme-substrate reactions.

Further reading (Hemker and Hemker 1969) will reveal to what extent the differences between the coagulation system and the Michaelis - Menten model of enzyme action influences the kinetics observed.

\author{
Yours sincerely, \\ Prof. Dr. H. C. Hemker, \\ Department of Biochemistry, \\ Rijksuniversiteit Limburg, \\ Maastricht, The Netherlands
}

\section{Reference}

Hemker, H. C. and Hemker, P. W. (1969): The Kinetics of Enzyme Cascades. Proceedings of the Royal Society. 173, 411. 